\title{
Diagrammatic Iconicity in EkeGusii: A relation between the structure of form and meaning
}

\author{
Elijah Omwansa Mariera * \\ (Kisii University, Kenya) \\ Evans Gesura Mecha ** \\ (Kisii University, Kenya) \\ George Morara Anyona *** \\ (Kisii University, Kenya)
}

\begin{abstract}
This paper mainly presents evidence for a relationship between language structure and meaning in EkeGusii, a Bantu language spoken in Kenya. The main argument is that the structure of language mirrors the structure of reality. A brief overview of other scholars demonstrates that diagrammatic iconicity shows universal tendencies. Five main ideas run down the discussion. Firstly, in EkeGusii, speakers sub-consciously cluster sounds around related meanings, evidencing gestalt and relative iconicity. Secondly, there is evidence of overlap of morphological and phonetic iconicity, an aspect of phonaesthesia. Thirdly, reduplication in certain infinitives demonstrates the reality of phono-iconicity in EkeGusii, augmented by unpleasant sound sequences. Fourthly, certain onomatopes in EkeGusii are actually diagrammatic, indicating that there is no one stop criterion for classifying overlapping types of icons. And finally, the paper posits that iconicity intersects with arbitrariness showing that language has both motivated and discrete symbols.
\end{abstract}

Keywords: elisive reduplication, phonaesthesia, echoic transparency, diagram, gestalt and relative iconicity

\section{Introduction}

\footnotetext{
Acknowledgments: Special gratitude goes to Professor Mark Dingemanse of Radboud University, wintry Nijmegen, the Netherlands, for correspondence that influenced the direction of arguments in this paper. We deeply appreciate the support of the two anonymous reviewers whose suggestions improved the overall shape of this paper.

* Elijah Omwansa Mariera: Department of Linguistics, Languages and Literature, Kisii University, Kilgoris, Kenya. E-mail: omwansaelijah@gmail.com.

** Dr. Evans Gesura Mecha: Senior Lecturer, Department of Linguistics, Languages and Literature, Kisii University. E-mail: evans-mecha@kisiiuniversity.ac.ke.

*** Dr. George Morara Anyona: Lecturer, Department of Linguistics, Languages and Literature, Kisii University. E-mail: kaonianyona@yahoo.com.
} 
As Downing and Steibels (2012) observe, diagrammatic iconicity is considered most relevant to linguistic analysis of language structure. They define reduplication as the systematic repetition of all or part of the phonological material of a base for derivational or inflectional purposes. The distinction between reduplication, as a morphological process that happens within words, and prosaic repetition, as a syntactic or discourse phenomenon, is clarified in Kwon (2017). Reduplication is one of the forms of diagrams exhibited in EkeGusii. Further, diagram is manifested in phonaesthesia where there is motivation in sound-size and/or sound-shape symbolism, another form of homologous relations. This paper pursues a narrow line of iconicity arguing for iconic mappings between word structures and meanings in EkeGusii, leaving out a larger chunk of iconized lexical material that may fall outside diagrammaticity, part of which is in Mariera (2020) and other detail explored in Mariera (2021). However, there is an attempt to argue that forms such as diagrammatic and imagic iconicity tend to overlap at some point, presenting it more as a research agenda than a conclusive position. It will be noted that a satisfactory description of certain iconic material in EkeGusii, arguably warms up towards conceptual metaphor theories. The presentation is mainly exploratory, pegged on the view that EkeGusii is yet to be demonstrated as a considerably iconized language. Several lexical items in EkeGusii are losing their iconic status, or becoming blurred. This poses challenges for research and description. The discussion, as well, presents a brief overview of the iconicity-arbitrariness interface. While diagrammaticity could equally be established in other lexical items like iconic ideophones and onomatopes (distinction in Mariera, 2021), the discussion focuses on the description of salient data in EkeGusii for its arguments.

\section{Diagrammatic icons}

According to (Brdar, 2013), quoting Haiman (1980), in Diagram, the structure of the language directly reflects some aspects of the structure of reality. In the same vein, Dingemanse (2015), observes that in diagrammatic iconicity, structural relations and modifications in one domain have analogical correspondences in another domain. While 'diagrammatic iconicity' is associated with Bybee (1985a \& b), Peirce (1955 [1902]) divided signs into icons, indices and symbols (Ajello, 1995; Hiraga, 1994, 2005; van Langendonck, 2007). According to Hiraga (1994:7), of the three subtypes of icons (images, diagrams, and metaphors), "diagrams (e.g. maps and floor plans) exhibit a structure analogous to the structure of their object (e.g. territories and buildings)". In diagrams there are analogous relations in their own parts that show relations of the parts of an object. Between the diagram and its object there is a similarity that is dyadic, relational, or structural analogy (see also, Pietrandrea, 2007). Diagrams are either structural or relational. Structural diagrams show correspondence between the structure of form and the structure 
of content, while relational diagrams show a tendency to associate sameness in form with sameness in content. Detail of the divisions of diagrams is in Hiraga (1994).

The situation in EkeGusii diagrams appears well brought out in reduplication (where more form means more content), morphological augmentation, phonetic symbolism, and in cacophonous clustering of sounds where sound structures reflect the structure of reality. As Dingemanse (2015) observes, replication lends itself to the depictive use of speech, that is, by way of iconically suggesting meanings in the domains of repetition, iteration, and distribution, but it cannot be limited to such. With insight from Fischer (2011) who discusses ablaut reduplication, it will be evident that in EkeGusii sounds are elided, and to some extent, indirect onomatopoeic reduplication coupled with iconized morphological augmentation is manifested in a complex or 'chaotic' system as argued in Ma Qinghua (2018), as will be established in this paper.

\section{Diagrammaticity as a universal tendency}

Downing \& Steibels (2012) quoting Kouwenberg \& LaCharite (2005:534) refer to the iconic principle of reduplication thus: "More of the same form stands for more of the same meaning." They observe that reduplicative morphology is associated with iconic meanings, this being one of the many ways in which diagrammatic iconicity is manifested in language. For instance, they quote Moravcsik (1978:321) who gives Sundanese examples like hayay 'want' and hayay-hayay 'want very much', and, rame 'jolly' and rame-rame 'be very jolly' among others. Brdar (2013) has conducted an extensive comparison of data from Germanic, Romance, Slavic, and Finno-Ugric languages adducing evidence of the universality of diagrams in both full and partial adjective reduplication. Examples include those cited from Singh and Wee (2002:519) like cough-cough-cough 'keep on coughing' in colloquial Singapore English, qata-za-za-zay 'ceaselessly turn the head from side to side', in Thao, an Austronesian language of central Taiwan, and hi-hi-hiki 'to come or go, of many people' from Hawaiian in Blust (2001), showing triplication, beyond reduplication. He further notes that though rare, quadruplication and quintuplication have been attested in Thao (Blust, 2001:333f) and in Riau (Gil, 2005:55). Brdar also cites examples like teeny-weeny 'very small', herky-jerky 'spasmodic, irregular, and unpredictable' and rissz-rossz 'very bad' as cases of ablaut-motivated reduplication from English, Australian English and Hungarian in that order, while tanda-manda 'confused, disorganized' is a case of rhyme-motivated reduplication from Romanian. From Estonian, sini-sinie 'blue-blue' can be taken as an example of partial reduplication with truncation. Diagrammaticity is further evidenced from reduplicative Siwu ideophones and repeated talk by Dingemanse (2015) who finds them framed as depictive amid otherwise descriptive material. Dingemanse cites examples like pipia 'put repeatedly', màfuri màfuri 'albinos here and there', sinisini 
'woven tightly', and kpstsro-kpotsro 'moving like a tortoise'. Dingnemanse adduces further evidence of diagram in Emai, an Edoid language of Nigeria, in Semai, an Aslian language of peninsula Malaysia, and in Korean, attesting to the universality of diagrammaticity. Kwon (2017) conducts a multi-dimensional examination of reduplicative processes occurring in mimetic and Yamato items in Japanese with rich details of exemplification and analysis, focusing on total reduplication.

\section{Sources and scope for EkeGusii diagrams}

Data for EkeGusii diagrams herein has been pulled together from a number of sources. A majority of data has been gotten from a careful examination of the lexical entries in the 'authoritative dictionary of EkeGusii, endabaro, endabasia y'ekegusii' by Bosire and Machogu (2013). Other substantial data has been collected from speakers of EkeGusii by way of unstructured interviews geared towards eliciting relevant lexical items for analysis and description. The third source is the native speaker intuition of the researchers which enabled the supply of relevant material. One intuitively generated lexical item, eng 'urang'uri 'the adamant creeper', has been glossed with reference to Mwalimu (2019) and Omwenga (2015), two secondary sources for comparative purposes, wherein the final vowel $a$ is speculated to have been elided but instead a causative morpheme is used in its place. On matters of scope, this paper is limited to data that may be associated with diagrammatic iconicity, where the structure or sequence of elements, morphemes or sounds, can be associated with reality. While there is a distinction between ideophones and onomatopes in EkeGusii that has not been outlined herein (see Mariera, 2020, 2021), this paper has attempted to establish a link between imagic and diagrammatic iconicity where onomatopes appear depictively reduplicative. Fundamentally, the discussion has evaded a wide range of forms of iconicity in EkeGusii such as iconic lengthening, iconic prosodic variation, ideophonicity and onomatopoeia, among others (which detail is in Mariera, 2021), to focus on and highlight diagrammaticity. It should be noted that this paper makes no claims for an exhaustive discussion around diagrammatic icons in EkeGusii, but sheds light on the possible extents of such isomorphism by availing a preliminary description as a precursor to more systematic investigation in the future.

\section{Phonaesthemic and morphological iconicity}

Two sub-types of diagrammatic iconicity, relative and gestalt, can be evidenced by reduplication in EkeGusii. Gasser, Sethuraman \& Hockema (2005) define relative iconicity as the property of a set of words to which there is a correlation between form similarity and meaning similarity. Dingemanse (2011) clarifies that the relationship between forms resembles the relationship between the concepts they refer to. Though Smoll (2014) 
correctly observes that quite often more than one type of iconicity will be at work in words (especially ideophones). The concept here is that of De Cuypere (2008) where a sound cluster is related to a certain meaning based on association with similar sound clusters, that is, phonaesthemes. In such a case it is possible to distinguish word-affinity- relations or word constellations. In reference to Ohala's (2008) frequency code, Smoll (2014) notes that although the relationship between form and meaning may be arbitrary, the iconicity lies in the relationship between words with similar forms and which have similar meanings. On the other hand, in gestalt iconicity, relationships between forms relate to the concepts they refer to.

\subsection{Phonetic diagrams}

In Table 1, sound /t/ occurs stem-initially in all the lexical items. Except for the examples (s-v) which are infinitival forms, the rest are nominal forms. The consonant sounds are followed by vowel sound $/ u /$ in (a-f), vowel $/ i /$ in (g-l), and vowel $/ a /$ in (m-t). The glosses given may not be assumed absolute as other speakers may paraphrase them variously, though the meanings will still be related and close to the ones given. The point of interest is to examine the nature of meanings associated with the stem-initial sound / $t /$ in EkeGusii nouns and infinitives as given in Table 1.

Table 1. Phonaesthemes of sound $/ t /$

\begin{tabular}{|c|c|c|c|}
\hline & Lexical item & Transcription & Gloss \\
\hline (a) & ebi-turuturu & [eßituruturu] & 'abominable acts' \\
\hline (b) & obo-turubanu & [oßoturußanu] & 'behavioural instability' \\
\hline (c) & obo-turutumbi & [oßoturutumbi] & 'awful actions' \\
\hline (d) & obo-tumanu & [oßotumanu] & 'misappropriation' \\
\hline (e) & obo-tutukanu & [oßotutukanu] & 'confusion' \\
\hline (f) & obo-tindu & [oßotindu] & 'drunkenness' \\
\hline$(\mathrm{g})$ & obo-tirigoyu & [oßotiriyoju] & 'chaotic behaviour' \\
\hline (h) & obo-tindi & [oßotindi] & 'brutality' \\
\hline (i) & obo-tiororoku & [oßotiororoku] & 'hornbill-like behaviour' \\
\hline (j) & obo-tibongi & [oßotißongi] & 'the act of rape' \\
\hline$(\mathrm{k})$ & obwe-an-tagari & [oßueantayari] & 'pride/show-off' \\
\hline (1) & obo-tabagu & [oßotaßayu] & 'wretchedness' \\
\hline$(\mathrm{m})$ & obo-taka & [oßotaka] & 'poverty' \\
\hline$(\mathrm{n})$ & obo-tantanu & [oßotantanu] & 'confusion' \\
\hline$(0)$ & obo-tayayi & [oßotajaji] & 'loitering and/or immoral conduct' \\
\hline$(p)$ & obwe-takori & [oßuetakori] & 'boastful talk' \\
\hline (q) & obwe-tangareki & [oßuetangareki] & 'know-it-all behaviour' \\
\hline
\end{tabular}


Diagrammatic Iconicity in EkeGusii: A relation between the structure of form and meaning

\begin{tabular}{|c|c|c|c|}
\hline$(\mathrm{r})$ & ogo-tuguta & [oyotuyuta] & 'to throw away' \\
\hline (s) & ogo-tung 'atun'ga & [oyotuyatuya] & 'to move confusedly' \\
\hline$(\mathrm{t})$ & ogo-tiringa & [oyotiringa] & 'to dirty, to soil' \\
\hline (u) & ogo-tibogeria & [oyotißoyeria] & 'to wade in mud' \\
\hline (v) & ogo-tang'ang'a & [oyotayaya] & 'to be puzzled, bewildered' \\
\hline
\end{tabular}

The impression one gets from these 'phonaesthemes' is that of sounds clustering to convey related themes. The point of interest is not whether the meanings conveyed are aesthetic but whether the sounds are strikingly clustered or sequenced to convey related topical ideas, messages or impressions. Indeed, the alveolar plosive / $t /$ symbolically recurs stem-initially in nominal and infinitival lexical items that express a sense of 'the unlikeable, the undesirable, the disgusting, the horrible' and so forth. Generally, the meanings put across all bend over to the negative. From Whiteley (1960), Cammenga (2002) and Nash (2011), the voiceless alveolar plosive $/ t /$, appears in the EkeGusii negative prefixes, $\{t i-\}$ or $\{t a-\}$. As Cammenga (2002) observes, a deletion rule applies on the vowel /i/ before any other vowel applies in any other tense. We are concerned with the behaviour of the negative-marker $\mid t /$ which in this case is considered phonaesthemic. From Cammenga's insight, we may therefore presume that the underlying sequence in all the items in table 1 is $\{\boldsymbol{t i}-\}$ which allows other vowels $/ u /$ or $/ a /$ to apply in the place of $/ i /$ after its deletion. A number of the stems are either fully or partially reduplicative (with slight modification), or the stem initial segments are followed by some other discordant sequences of sounds that convey the meaning component [UNLIKEABLE]. It therefore turns out that stem-initial and possibly replicated $/ t /$ depicts the 'unlikeable'.

We need to raise questions concerning the speaker's mind. Do speakers cluster such sounds consciously? Are speakers aware that there exists such an association between the sounds in such words and their referents? Obviously, they are not. So the mind subconsciously associates sound $/ t /$ to the negative, implying what the mind has to do with the perception of the 'unlikeable'. On closer examination of the articulation of $/ t /$, the blade of the tongue is raised to the alveolar ridge, and on release of the obstructed air, it creates plosive noise, perhaps indicating a sub-conscious desire to [REJECT]. This might explain why sound $/ t /$ recurs in relation to negative connotations. The position and function of this sound are by no means arbitrary or descriptive but arguably depictive and semantically suggestive in line with Dingemanse's (2015) argument on depiction. Interestingly, speakers articulate this sound performatively, that is, with extra prosodic features such as little force that may be termed stem-initial syllabic stress, and raised loudness that comes after a kind of prefixal pause, which make the stem initial syllable attract articulatory salience which is therefore depictive as opposed to descriptive (arbitrary). Further evidence of the depictive 
nature of the sound lies within its replicative nature, partial or full as in examples (a), (c), (e), (n) and (s). By no means can the prosaic patterning qualify sound $/ t /$ as iconized, but its seemingly motivated semantic and prosodic traits that make it depictive of particular meanings, in as much as there is always a link between motivation and arbitrariness.

De Cuypere (2008) gives examples from English like crash, dash, clash, gash, gnash, smash, flash, in which the words involve sound $/ / 7$, which is related to explosion or collapse. As Elleström (2013) observes, the speakers' perception is always an interpretation of the external world. Information reaching the brain may not be systematically arranged but is a collection of more or less separate signals that the brain puts together into a comprehensible unity. In the same vein, there is a way in which the speakers of EkeGusii relate sound $|t|$, and certain vowel patterns, with the sense of [DISLIKE]. This scenario is comparable to a situation encompassing both morphological and phonetic iconicity discussed below in relation to the data in Table 2.

\subsection{A morphological and phonetic symbolism intersection}

According to Elleström (2013), the distinction between perception and imagination is blurred. Arnheim (1969) supports this position by observing that in the perception of shape lie the beginnings of concept formation. From the data in Table 2, it should be observed that the subject marker morpheme $\{\boldsymbol{r i}-\}$ in EkeGusii is related to mental shapes associated with the meaning component [HUGE] plus a negative sense such as [UGLINESS], [DISTORTION], [HIDEOUSNESS], [GRUESOMENESS], or [UNSIGHTLINESS] and so forth, carried out by the following discordant sound sequences. How an object is perceived is related to how it is subconsciously interpreted. All the examples in Table 2 are nominal references relating to people of perceived negative qualities and implied mental shapes. Except (a) and (b), the rest were drawn from Bosire \& Machogu (2013). The examples also provide clearer evidence of phonaesthesia, size-sound symbolism, the concept that lies within synesthesia according to Fordyce (1988).

Table 2. Nouns referring to people in the negative sense

\begin{tabular}{l|l|l|l}
\hline & Noun & Transcription & Gloss \\
\hline (a) & ri-koneke & [rikoneke] & 'disorganized person' \\
\hline (b) & ri-gene & {$[$ rifene] } & 'someone hard to learn' \\
\hline (c) & ri-chara & {$[$ ritfara] } & 'idiot, fool' \\
\hline (d) & ri-komo & [rikomo] & 'dweeb' \\
\hline (e) & ri-kunyati & [rikunati] & 'foolish person' \\
\hline (f) & ri-mansu & [rimansu] & 'dumb person' \\
\hline (g) & ri-maya & [rimaja] & 'idiot' \\
\hline (h) & ri-mama & [rimama] & 'dumb, temporarily unable to speak' \\
\hline
\end{tabular}


Diagrammatic Iconicity in EkeGusii: A relation between the structure of form and meaning

\begin{tabular}{|c|c|c|c|}
\hline (i) & ri-gata & [riyata] & 'paralytic' \\
\hline (j) & ri-bagoki & [rißayoki] & 'loose talker' \\
\hline$(\mathrm{k})$ & ri-kangi & [rikangi] & 'tart' \\
\hline (1) & ri-mong'o & [rimono] & 'a stupid, annoying person' \\
\hline (m) & ri-ochi & {$[\operatorname{riot} \mathrm{i}]$} & 'infantile' \\
\hline (n) & ri-tendu & [ritendu] & 'lay-about' \\
\hline (o) & ri-urugenye & [riuruyene] & 'a huge, lazy person or polar bear' \\
\hline (p) & ri-kara & [rikara] & 'someone naïve or piece of charcoal' \\
\hline (q) & ri-geki & [riyeki] & 'glutton or a rodent' \\
\hline (r) & ri-kanabo & [rikanaßo] & 'an impotent man or a stingless bee' \\
\hline
\end{tabular}

Going back to the prefixal subject marker $\{r i-\}$, the speakers use it in nominal references to convey meanings related to 'unattractively BIG', that is [HUGE and UGLY]. This underlying size-symbolism is the concept related to the implied mental shapes in all the nouns. The morpheme connotes to 'too-big-to-like', so that in most cases, it relates to a form of socio-psychological ugliness. Of course in other cases, the morpheme has positive connotations as in ri-entenyi [rienteni] 'a rich person', ri-mura [rimura] 'an energetic young man' and so forth, but the stems in such cases are already in the positive so that the morpheme only amplifies the positive quality. Notably, in such cases, speakers and hearers appeal to relevant pragmatic factors to transact intended meaning impressions. In the cases in Table 2, the stems connote to negative meaning, which may not be clear unless the subject marker $\{r i-\}$ is prefixed. In a sense, the stems are nearly meaningless on their own, non-words of a kind; the stems sound partially arbitrary on their own but clearly iconized with prefixation. Precisely, the prefixes become iconized absolute augments that go beyond ordinary prefixal forms. However, as noted already, the discordance of the stem sound patterns complements the phono-iconic aspect of the words; the dissonance of the stem sound sequences is actually unappealing in the ear of a native speaker, implying 'rejectability'. It is only an example in (h) ri-mama [rimama] 'dumb' where the stem can be said to function as an onomateme, that is echoic of the sounds made by the dumb, but the replicative depiction renders it diagrammatic. Arguably, it is the prefixal morpheme $\{r i-\}$ that affords and augments the stem patterns their depictive function.

In examples (o-r), the stems carry the original meanings of the nouns so that the meanings related to people may be considered more of metaphoric than direct references; the meanings are actually transferred. For instance, rikanabo [rikanaßo] 'a stingless bee, or a bee with a non-poisonous sting' is comparable to a man that cannot perform conjugal duties as indicated in (r). In (o), riurugenye [riuruyense] 'polar bear' is a slow and lazy-looking animal, despite its size, muscle build and energy. This is metaphorically 
transferred to a person with such qualities. Such examples may also be explained in the light of Lakoff \& Johnson's (1980) conceptual metaphor theory, where A, the target domain, is understood in the light of B, the source domain. The stingless bee and the polar bear are the source domains that help understand the target domains, impotent and lazy people. This situation is comparable to what Köhler (1929) discovered in Spanish speakers. They match the non-word maluma with a curvy, round shape and takete with spiky, angular shape. Fonagy (1961) found sounds $/ \mathrm{l} /$ and $/ \mathrm{m} /$ to occur more in tender poems but $/ \mathrm{k} /$ and $/ \mathrm{t} /$ more in aggressive poems. EkeGusii stretches beyond phonological iconicity to draw mappings between morphemes and referents, which is on the one hand a form of morphological iconicity, yet owing to the sound sequences that follow, it borders on phono-iconicity.

Schmidtke, Conrad \& Jacobs (2014) have observed that in phonaesthemes, phonemes cluster as syllable onsets or as rhymes, in words that belong to specific semantic fields, as in Table 2. Phonaesthemes facilitate the participant's ability to deduce new meanings even outside of context. The examples of clusters given in bold-face from Thai by Rungrojsuwan (2009), involve initial consonants like /kru,ap/ 'chewing hard', /khlitin/ 'thundering', /khla_k/ 'boiling rice', /khriin/ 'thundering', and others are onomatopoeic, but they demonstrate the tendency of languages to cluster sounds at certain word positions for the purposes of meaning.

\section{Cacophonous phono-iconicity and reduplication in infinitives}

The reality of both gestalt and relative iconicity is evident where in the former there is a relationship between the structure of words and what they refer to, and in the latter, relationships between forms relate to the concepts they refer to. Cacophony may be explained in relation to sounds being perceived as 'auditorily unpleasant', as a result of them sounding dissonant (detail in Mariera, 2021). Cacophonous sounds make words feel repulsive and once such sound elements are reduplicated, it allows EkeGusii to communicate negative meaning impressions as a result of the consequential disharmony. It can be argued that the reduplicated stem parts are pseudo-words or 'non-words' which to the native speakers are imbued with context-dependent or context-modulated meaning components rendered via reduplication. The pre-prefixes and class-prefixes only perform infinitival morphological functions (Bickmore, 1997; Cammenga, 2002; Nash, 2011), under the morphological structure of EkeGusii infinitives. Comparably, Ma Qinghua (2018) noted that in onomatopoeia, quasi-language evolves into real language. The data in Table 3 is a collection of cacophonous and reduplicative infinitives related meaning components that may be collapsed as [UNATTRACTIVE]. 
Diagrammatic Iconicity in EkeGusii: A relation between the structure of form and meaning

Table 3. Cacophonous and reduplicative infinitives

\begin{tabular}{|c|c|c|c|}
\hline & Infinitive & Transcription & Gloss \\
\hline (a) & oko-mayamaya & [okomajamaja] & 'to loiter' \\
\hline (b) & oko-mangamanga & [okomangamanga] & 'to linger' \\
\hline (c) & oko-magamaga & [okomayamaya] & 'to look suspiciously' \\
\hline (d) & ogo-segasega & [oyoseyaseya] & 'to move up and down in tension' \\
\hline$(\mathrm{e})$ & ogo-saagasaagia & [oyosa:yasa:yia] & 'to eat inattentively' \\
\hline (f) & oko-riimariima & [okori:mari:ma] & 'to stumble, wallow in darkness' \\
\hline$(\mathrm{g})$ & oko-miiramiira & [okomi:rami:ra] & 'to move fast confusedly' \\
\hline (h) & oko-ruumaruuma & [okoru:maru:ma] & 'to act hastily' \\
\hline (i) & ogo-karakaria & [oyokarakaria] & 'to rummage through objects' \\
\hline (j) & ogo-kaarakaaria & [oyoka:raka:ria] & 'to do hurriedly' \\
\hline$(\mathrm{k})$ & ogo-keerakeeria & [oyokeerakeeria] & 'to do roughly' \\
\hline (1) & oko-raagaraaga & [okora:yara:ya] & 'to walk around aimlessly' \\
\hline (m) & oko-garagaria & [okoyarayaria] & 'to annoy' \\
\hline$(\mathrm{n})$ & oko-beegabeega & 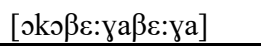 & 'to act lazily' \\
\hline (o) & oko-gwong'agwong'a & [okoyuoyayuona] & 'to move confusedly' \\
\hline (p) & oko-ng'warang'waria & [okoyuarayuaria] & 'to do unattractively' \\
\hline
\end{tabular}

The consonant sequences that recur in the stem reduplicates can be identified down the list in the following order: $|m-j|,|m-\eta g /| m-,\gamma /,|s-\gamma /| m-,r|| r-,m|| k-,r|| r-,\gamma|,| \gamma-r|,| \beta-\gamma \mid$, $/ w-\eta /$ and $/ \eta-r /$, in that order. An attempt to articulate the sequences without the intervening vowels makes them all feel jagged or rough, and coupled with a sense of discord that makes them articulatorily and auditorily repugnant. For instance, the sequences with flaps at the beginning or the end of the reduplicated stem, imply the meaning component [ROUGH] as in oko-riimariima [okori:mari:ma] 'to stumble or wallow in darkness' in (f), ogo-keerakeeria [oyokeerakeeria] 'to do roughly' in (k), and oko-gaaragaaria [okoya:raya: ria] 'to annoy' in (m). The articulatory shifts from an alveolar flap to a nasal, velar plosive to an alveolar flap, velar non-sibilant fricative to an alveolar flap in that order creates the impression of a rough articulatory experience which conveys the meaning component [ROUGH] or unlikeable. A closer examination of any of the sequences picked at random

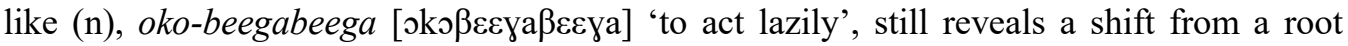
initial bilabial fricative to a velar non-sibilant fricative. With reduplication of the base, it depicts and exploits the recurrent unpleasantness. Similarly, example (b) oko-mangamanga [okomangamanga] 'to linger or move about questionably' has a movement from a bilabial nasal to a complex nasalized homorganic sound, suggestive of unpleasantness. Generally, the impressions are conveyed by the nature of sounds that occur in the strings, the order of 
occurrence, the stem-initial or stem-final selections, and the reduplication of the stems. As noted in Dingemanse (2015), reduplication cannot be a criterion for iconicity. Several reduplicative forms are not iconized in EkeGusii. What counts is if the reduplicants are depictive as opposed to being descriptive, or prosaic (Kwon, 2017).

The examples in (i-k) for instance have the sound sequence $/ k-r /$ which sounds mimetic of noise from something that is being done hurriedly, in a disorderly or careless manner. The same happens in the consonant sequence $/ \eta-r /$ in (p). The meaning components in all of them are related to $[\mathrm{ATTACK}]+[\mathrm{HURRY}]$ which gives unattractive meaning results. [CARE] is not one of the components. Such an observation could arguably be language-bound since each language has its own order of sounds and words, but for the native speakers of EkeGusii, and perhaps other languages with which EkeGusii shares higher mutual intelligibility may identify with such impressions. Since EkeGusii is a strict CV language (Anyona, 2017), the consonant sequences must allow the intervening vowels, in obedience to the phonotactics of the language, for the strings to convey sense. The duplicated non-words therefore attain the sense of things happening in ways unorthodox. As Croft (2003) observes, the structure of language can reflect in some way, the structure of experience; contiguity, quantity, repetition, complexity, cohesion. The data in Table 3 agrees with the "Iconicity of sequence principle" noted in Perniss, Thompson \& Vigliocco (2010), which holds that the sequence of forms conforms to the sequence of experience. The data may therefore be treated as sound symbolic words, where the properties of the consonants and the patterns of combination with the vowels coupled with reduplication, convey sensory events. In such examples, perhaps, one would wonder how far or how close they are from onomatopoeia. Certain implicit onomatopoeic stems as these, the stems lacking echoic transparency, display depictive reduplication, which structural form turns out diagrammatic hence a convergence of imagic and diagrammatic iconicity as will be elaborated in $\S 7$ below.

From Table 3, examples (e), (i), (j), (k), (m), and (p), show evidence of internal stem change where the second part of the reduplicated base incorporates a causative morpheme, $-i$. The question that must be addressed is whether the causative morpheme is elided in the first part or epenthesized (inserted) in the second. Examining the general morphological behaviour of reduplication in the language, especially instances of meaningful isolated bases with causative morphemes such as seria [seria] 'send away', and mieria [micria] 'dance' which appear in reduplicants as in seraseria [seraseria] 'send away repeatedly', and mieramieria [micramicria] 'dance repeatedly', it becomes apparent that this causative morpheme is elided in the first part of the reduplicative base for ease of articulation. The same morphological pattern is witnessed in the mentioned iconized examples whose bases may be termed indirectly onomatopoeic or echoic. EkeGusii therefore displays a 
morphological process that can be termed as deletive or elisive reduplication, pegged on 'deletion or elision' as ordinary morphological processes.

\section{A conjunction of diagrammatic and imagic iconicity}

Mainly collected from Bosire \& Machogu (2013), apart from example (a), the below data will be used to advance the argument that diagram is not an unadulterated type of iconicity in EkeGusii as evidence of overlapping will be very clear. Essentially, all the examples are nouns built on echoic bases, onomatemes, whose reduplication in turn signals the more-form-more-content sense of diagram. While echoic bases can be said to signal imagic iconicity, it should be noted that such bases as in the below data cannot be considered explicit but implicitly mimetic, which is indirectly imitative, as opposed to transparent mimesis (see detail in Mariera, 2020). Once part of the reduplicative base implies translucent imitation, the reduplicant attains its diagrammatic status which allows an intersection of diagrammatic and imagic icons.

Table 4. Diagrammatic onomatopes

\begin{tabular}{l|l|l|l}
\hline & Noun & Transcription & Gloss \\
\hline (a) & e-ng'urang'uria & [ejuranuria] & 'creeper herb, cissus quadrangularis' \\
\hline (b) & e-kurukuru & [ekurukuru] & 'turkey' \\
\hline (c) & o-bo-rundarundia & [oßorundarundia] & 'swings' \\
\hline (d) & e-ke-rondarondia & [ekerondarondia] & 'wavy pattern as in child's writing' \\
\hline (e) & e-ke-mbugumbugu & [ekemburumbuyu] & 'stormy wind' \\
\hline (f) & e-gurugura & [eyuruyura] & 'drought' \\
\hline
\end{tabular}

Example (a), e-ng'urang'uria 'the adamant creeper', which has been given a botanical name rubia cordifolia (Omwenga, et. al., 2015) and cissus quadrangularis (Mwalimu, 2019) appears in both sources without the final vowel, -a (present in other regiolects), which should allow the segment - $\mathrm{i}$ - to function as a causative morpheme (discussed in $\S 5$ above) as it also appears in related examples, (c) and (d). The perennial herb has a rough surface on both its weak stems and leaves. Being a creeper, it commonly grows on natural fences and hedges. The base sound sequences /yur/ are depictive of the corrosive effect of the plant on the skin around the hands, or even the resultant noise made when pulling it off the hedges or fences, being 'adamant', which has afforded it its metaphorical name, the 'adamant creeper'. This corrosive effect can be felt over and over while handling this herb even when dried so long as it has not been turned into another form such as powder. This repetitive corrosive effect is depicted by the reduplicative base to which the nominal prefix e- is attached. Treating the sequence /yur/ as implicitly echoic, we arrive at an imagic icon which replicates still depictively, which string is rendered diagrammatically. At this point, 
the two forms of iconicity converge, not because there is replication but because there is depiction as opposed to description. Duplication is here evidenced as a motivated morphological process. Example (b) is a pure onomatope (see more examples in Mariera, 2020) where the root of the first part, $/ k u r /$, is onomatemic, but since the depicted domestic bird makes such noise repeatedly, the echoic part has to replicate; the bird produces /kur kur/ sounds, hence its name. Several onomatopes in EkeGusii, especially those naming animals and birds are likely to strike kinship to both diagram and image. The other root sound sequences from (c-f), /run/, /ron/, /bur/, and / $\mathrm{zur} /$, can also be analyzed as implicitly depictive of reality. The sound $/ d /$ in (c-d) is assimilated to the place of articulation of the underlying $/ r /$ in both cases realized as the alveolar $/ n /$ leading to the cluster $/ n d /$, and in (e) the sound $/ \mathrm{m} /$ is assimilated to the underlying bilabial fricative $/ \beta /$ leading to the consonant cluster $/ \mathrm{mb} /$, which homorganic sounds are treated as single consonants.

One challenge that may face linguistic investigation and analysis around iconicity is that posed by the loss or degeneration of the iconic value of a number of lexical items in EkeGusii. For instance, words such as obochingiriri [oßotingiriri] 'sensitivity to foreign touch', obotoratoria [oßotoratoria] 'gossip', okoranderera [okoranderera] 'to wind something around another', obomangamangi [oßomanyamanyi] 'to look around in an unsettled manner', and many others, appear either iterative or reduplicative and sound to native speakers as potentially iconized which feature however, is getting fuzzy. However, as Dingmense (2015) and Kwon (2017) observe, not all reduplication is iconic. Moreover, from the foregoing, it appears that several imagic icons are possibly diagrammatic, which calls into question any attempt at a purist criterion for classification. Nevertheless, this points clearly that diagrammatic and imagic icons should rather be examined as potentially uninsulated against each other.

\section{The iconicity-arbitrariness interface}

A closer examination of iconized words in EkeGusii reveals that an attempt at the description of human language could be more complex than can be imagined, or chaotic. Certain words like example (o) of Table 3, oko-gwong'a-wong'a [okoyuonayuona] 'to move confusedly', indicate that EkeGusii has certain lexical items that are both arbitrary and iconic. The iterative stems sound translucently mimetic of noises of movement, perhaps of objects that displace air currents to afford such noises depicted by the consonants $/ g /$ and $/ \mathrm{y} /$. Isolated stems do not sound iconized but apparently arbitrary. For instance, gwong ' $a$ sounds almost meaningless, non-suggestive, and simply descriptive. In other words, the real iconic value of the root $/ g u o y /$ is actually obscured or suspended before iteration. In a sense, arbitrary or vaguely iconic sounds are combined to form stems which at the level of iteration attain iconic status, that they advance from a prosaic level 
towards a potentially 'ideophonic' status. The resultant iterative strings accommodate affixes whose result is the infinitival form oko-wonga-wonga 'to move confusedly'. The iconic function of iteration is achieved in the verbal dramatization of the movement happening now and again. In as much as this lexical item could be regiolectical, it can thus be used to demonstrate the intersection of the Saussareian and Peirceian views of language; language at some point could be viewed as both arbitrary, and motivated. Example (p), oko-ng'warang'waria [okoyuarayuaria] 'to do unattractively' would behave the same way where the $/ \mathrm{y} r /$ sounds of the isolated stem /yuar/ sounds prosaic at face value. However, this again may sound approximately imitative of one working with an object like a painting brush on a rough surface where the paint is spread unevenly. The perceived noise can be tailored by the duplicative consonant sequences /yrr $y r r /$, which require the impressionistically closest intervening vowel segments where $/ u /$ is preferred. With the resultant sequence $/ y u r /$, the phonotactics of the language will demand that the final vowel and other affixal and prefixal segments be attached. Such meaning impressions are transferred from a source whose background is vaguely traceable (precisely, impossible to trace) to a general usage where the lexical item can be used for haphazard cleaning of surfaces, painting, using oxen to plough land, drawing of lines, etc. By imagination, the human mind transfers meaning from one domain to another, a complex cognitive process. The subconscious can allow a speaker to use the word oko-ng'warang'waria in a novel context and correctly so, so long as the correct pragmatic factors are favourable for both the speaker and hearer. This view can be extended to the roots of the data in Table 3 from (a-h); may, mang, mag, sag, saag, rim, mir, and ruum, all of which are sound descriptive, that is unmotivated, in the ears of native speakers. The attachment of the final vowels to the first parts of the reduplicant bases does little good leaving them fairly arbitrary, which picture, however, changes with reduplication. In other examples like (f) oko-riimariima and (g) okomiiramiira there occurs a kind of phonemic lengthening within the bases that helps distinguish them from other meanings of the isolated bases with short vowels like okorimarima 'to die out repeatedly, of fire or light'. The moment the bases are reduplicated, beyond more form and more content, the words attain a degree of depiction or motivation that renders them 'translucently' iconized. This scenario may well be expressed in the words of Dingemanse (2015:964): "description and depiction are not insulated from each other and are best studied in conjunction."

Arbitrary iconization has also been observed by Marchand $(1959,1960)$ cited in Fordyce (1988) which includes slide, slither, slip, slouch, slump, slime, slush, slop, slough, slobber, sludge, and slosh, where the semantic correlate of this set is 'falling or sliding movement' and/or 'slimy/slushy matter'. The sequence $s l$ - is arbitrarily associated with its meaning. Other examples are presented from Ladd (1978) cited in Fordyce, (1988) including glitter, 
glimmer, glow, and gleam where the particle gl- has acquired an arbitrary sound-meaning association but its function in English is an iconic one. Equally, Pietrandrea and Russo (2007) have observed a co-existence of iconicity and arbitrariness in verbal and signed languages although they take on different forms and reach a different balance in the structures of the linguistic system.

\section{Conclusion}

From EkeGusii, it is evident that language is structured based on the structure of reality, thereby making it depictive. This is the basic concept in diagrammatic iconicity. It appears from previous researches that diagrams are universal in nature; several world languages display diagrammaticity. Four areas have been explored to establish diagrammaticity in EkeGusii. In particular, speakers use stem-initial sound $/ t /$ to depict negative meaning impressions with or without reduplication, or its full or partial recurrence. Within size-sound symbolism, contemporaneous morphological and phonetic iconicity is evident where the morpheme $\{r i-\}$ depicts negative impressions of size together with dissonant sound sequences that realize this picture. It has been observed that cacophony is a concept related to unpleasant sound sequences that occur within reduplicative infinitive stems that are equally depictive of negative meaning impressions. It is evident that EkeGusii deletes or elides its causative morphemes in the first parts of its reduplicants to ease articulation. Reduplicative onomatopes show evidence of imagic iconicity intersecting with diagramma -ticity, bringing to question puritanical or rigid approaches to the classification of forms of iconicity in EkeGusii. In the description of iconized metaphorical expressions, iconicity appeals to conceptual metaphor, a sister conceptualization within cognitive linguistics. This is a significant idea that has been highlighted but not developed herein which could be taken up by future research. It has also been observed that a number of iconized expressions are context-modulated, making pragmatic assumptions inevitable in future investigations. While EkeGusii has been established as fairly iconized, arbitrariness and iconicity do intersect, and as Dingemanse (2015) observes, the two aspects of language are not impermeable to each other.

\section{References}

Ajello, R. 1995. The Icon as an Abductive Process Towards Identity [A]. In R. Simone (ed.). Iconicity in language [C]. Amsterdam: John Benjamins Publishing Company, 77-83.

Anyona, G. M. 2017. Phonological and Morphological Nativisation of English Nouns Borrowed into EkeGusii: A constraint-based approach [D]. PhD Dissertation. Kisii: Kisii University.

Arnheim, R. 1969. Visual Thinking [M]. Berkeley: University of California Publishers.

Bickmore, L. S. 1997. Problems in Constraining High Tone Spread in EkeGusii [J]. Lingua, 102(4):265290.

Blust, R. 2001. Thao Triplication [J]. Oceanic Linguistics, 40(2):324-335. 
Diagrammatic Iconicity in EkeGusii: A relation between the structure of form and meaning

Bosire, K. M. \& G. K. Machogu. 2013. Authoritative EkeGusii Dictionary: Endabaro endabasia y'EkeGusii [M]. Nairobi, Kenya: EkeGusii encyclopedia project.

Brdar, M. 2013. Adjective Reduplication and Diagrammatic Iconicity [A]. In M. Liović (ed.). Dreamers and Scientists: Anthology in honor of the 70th anniversary of the birth of Branka Brlenić-Vujić [C]. Osijek: Josip Juraj Strossmayer University, 489-514.

Bybee, J. 1985a. Morphology: A study of the relation between meaning and form [M]. Amsterdam: John Benjamins Publishing Company.

Bybee, J. 1985b. Diagrammatic Iconicity in Stem-inflection Relations [A]. In J. Haiman (ed.). Iconicity in Syntax [C]. Amsterdam: John Benjamins Publishing Company, 11-47.

Cammenga, J. 2002. Phonology and Morphology of EkeGusii: A Bantu language of Kenya [M]. Köln: Rüdiger Köppe Verlag.

Croft, W. 2003. Typology and Universals [M]. Cambridge: Cambridge University Press.

De Cuypere, L. 2008. Limiting the Iconic: Iconicity and language and literature [M]. Amsterdam: John Benjamins Publishing Company.

Dingemanse, M. 2011. Ezra Pound among the Mawu: Ideophones and iconicity in Siwu [A]. In P. Michelucci, O. Fischer \& C. Ljungberg. (eds.). Semblance and Signification [C]. Amsterdam: John Benjamins Publishing Company, 39-54.

Dingemanse, M. 2015. Ideophones and Reduplication: Depiction, description, and the interpretation of repeated talk in discourse [J]. Studies in Language, 39(4):946-970.

Downing, L. J. \& B. Steibels. 2012. Iconicity [M]. Berlin: ZAS.

Elleström, L. 2013. Introduction: Instrumental and formal iconic signs [A]. In L. Elleström, O. Fischer \& C. Ljungberg (eds.). Iconic Investigations [C]. Amsterdam: John Benjamins Publishing Company, 1-10.

Fischer, O. 2011. Cognitive Iconic Grounding of Reduplication in Language [A]. In P. Michelucci, O. Fischer \& C. Ljungberg (eds.). Semblance and Signification, Iconicity in Language and Literature 10 [C]. Amsterdam: John Benjamins Publishing Company, 55-81.

Fonagy, I. 1961. Communication in Poetry [J]. Word, 17:194-218.

Fordyce, F. J. 1988. Studies in Sound Symbolism with Special Reference to English [D]. PhD Dissertation. Los Angeles: University of California.

Gasser, M., N. Sethuraman \& S. Hockema. 2005. Iconicity in Expressives: An empirical investigation [A]. In S. Rice \& J. Newman (eds.). Experimental and Empirical Methods [C]. Stanford: CSLI Publications, 1-18.

Gil, D. 2005. From Repetition to Reduplication in Riau Indonesian [A]. In Hurch, Bernhard (ed.). Studies on Reduplication [C]. Berlin: Mouton de Gruyter, 31-64.

Haiman, J. 1980. The Iconicity of Grammar: Isomorphism and motivation [J]. Language, 56(3):515-540.

Hiraga, M. K. 1994. Diagrams and Metaphors: Iconic aspects in language [J]. Journal of Pragmatics, 22:5-21.

Hiraga, M. K. 2005. Metaphor and Iconicity: A cognitive approach to analyzing texts [M]. New York: Palgrave Macmillan.

Köhler, W. 1929. Gestalt Psychology [M]. New York: Liveright.

Kouwenberg, S. \& D. LaCharite. 2005. Less Is More: Evidence from diminutive reduplication in Caribbean Creole languages [A]. In B. Hurch (ed.). Studies on Reduplication [C]. Berlin: Mouton De Gruyter, 533-546.

Kwon, N. 2017. Total Reduplication in Japanese Ideophones: An exercise in localized canonical typology [J]. Glossa: A Journal of General Linguistics, 2(1):1-31.

Ladd, D. R. Jr. 1978. The Structure of Intonational Meaning [M]. Bloomington: University of Indiana.

Lakoff, G. \& M. Johnson. 1980. Metaphors We Live by [M]. Chicago: Chicago University Press.

Ma Qinghua. 2018. The Significance of Onomatopoeia in Languagization: From the perspective of sound-meaning relationship under dynamic system principle [J]. Macrolinguistics, 6(1):43-62.

Marchand, H. 1959. Phonetic Symbolism in English Word Formation [J]. Indogermanische Forschungen, 64:146-168.

Marchand, H. 1960. The Categories and Types of Present-day English Word Formation (2 ${ }^{\text {nd }}$ Edition) [M]. Munchen: Verlagsbuchandlung. 
Mariera, E. O. 2020. Onomatopoeic Infinitives and Nouns in EkeGusii: Evidence for imagic and relative iconicity [J]. Macrolinguistics, 8(1):36-54.

Mariera, E. O. 2021. Prosodic Simultaneity and Iconicity in EkeGusii [D]. PhD Dissertation. Kisii: Kisii University.

Moravcsik, E. A. 1978. Reduplicative Constructions [A]. In J. Greenberg (ed.). Universals of Human Language III: Word structure [C]. Standford: Standford University Press, 297-334.

Mwalimu, J. N. 2019. Continuity and Change in the Indigenous Therapeutic Systems among the Abagusii of Nyamira County, Kenya, 1880-2010 [D]. MA Thesis. Nairobi: Kenyatta University.

Nash, C. M. 2011. Tone in EkeGusii: A description of nominal and verbal tonology [D]. PhD Dissertation. Santa Barbara: University of California.

Ohala, D. 2008. Phonological Acquisition in a First Language [A]. In J. G. H. Edwards \& M. L. Zampini (eds.). Phonology and Second Language Acquisition [C]. Amsterdam: John Benjamins Publishing Company, 19-39.

Omwenga, E. O., A. Hensel, A. Shitandi \& F. M. Goycoolea. 2015. Ethnobotanical Survey of Traditionally Used Medicinal Plants for Infections of Skin, Gastrointestinal Tract, Urinary Tract, and the Oral Cavity in Borabu Sub-county, Nyamira County, Kenya [J]. Journal of Ethnopharmacology, 176:508-514.

Peirce, C. S. 1955 [1902]. Logic and semiotic: Theory of signs [A]. In J. Buchler (ed.). Philosophical Writings [C]. New York: Dover, 98-119.

Perniss, P., T. L. Robin \& G. Vigliocco. 2010. Iconicity as a General Property of Language: Evidence from spoken and signed languages [J]. Frontiers in psychology, 1:1-15.

Pietrandrea, P. \& T. Russo. 2007. Diagrammatic and Imagic Hypoicons in Signed and Verbal Language [A]. In E. Pizzuto, P. Pietrandrea, R. Simone (eds.). Verbal and Signed Languages: Comparing structures, constructs and methodologies [C]. Berlin: De Gruyter, 35-56.

Rungrojsuwan, S. 2009. The Non-arbitrary Aspect of Language: The iconicity of onomatopoeic words in Thai [J]. Sky Journal of Linguistics, 22:251-276.

Schmidtke, D. S., M. Conrad \& A. M. Jacob. 2014. Phonological Iconicity [J]. Frontiers in Psychology, 5:80-84.

Smoll, L. I. 2014. Me: ruru, $\phi o k u$, and tfitowif: An analysis of ideophones in Katuena (Tunayana) [D]. MA Thesis. Leiden: Leiden University.

Singh, R. \& L. Wee. 2002. On So-called Triplication in Colloquial Singapore English and Thao: A response to Blust: In memory of Stan Starosta [J]. Oceanic Linguistics, 41(2):514-522.

Van Langendonck, W. 2007. Iconicity [A]. In D. Geeraerts \& H. Cuyckens (eds.). The Oxford Handbook of Cognitive Linguistics [C]. New York: Oxford University Press, 394-418.

Whiteley, W. H. 1960. The Tense System of Gusii [M]. Kampala: East African Institute of Social Research. 